\title{
Rafał Dubowski
}

\section{Ocena skutków prawnych regulacji zawartej w rządowym projekcie ustawy o Rzeczniku Praw Podatnika'}

Zdaniem autora opinii alternatywnym rozwiązaniem wobec utworzenia instytucji Rzecznika Praw Podatnika mogłoby być zreformowanie istniejących organów i ukierunkowanie ich działalności na ochronę praw podatnika. Proponowane rozwiązanie daje jednak podatnikowi kolejny instrument, z którego będzie mógł on skorzystać, gdy uzna, że jego prawa są zagrożone. Rzecznik Praw Podatnika będzie organem częściowo zależnym od jednego z organów podatkowych i dlatego osiągnięcie celów zakładanych przez projektodawcę może być utrudnione. Autor zauważa, że wątpliwości interpretacyjne może budzić przepis formułujący wymogi dotyczące doświadczenia zawodowego kandydata na Rzecznika Praw Podatnika.

Słowa kluczowe: ocena skutków regulacji, podatek, podatnik, projekt ustawy, rzecznik

Impact assessment of the Governmental Bill on the Ombudsman for Taxpayers: According to the author of the opinion, a solution alternative to establishing the institution of the Ombudsman for Taxpayers could be reforming the existing bodies and focusing their activities on protecting the rights of the taxpayer. However, the proposed solution provides a taxpayer with another instrument which might be used when the taxpayer considers that his/her rights are at stake. The Ombudsman for Taxpayers will be partially dependent on one of the tax authorities and therefore it may be difficult to achieve the objectives set by the sponsor of the bill. The author notes that the provision formulating the requirements concerning the professional experience of the candidate for the Taxpayer's Ombudsman may raise doubts as to its interpretation.

Keywords: impact assessment, tax, taxpayer, bill, ombudsman

Doktor nauk prawnych, ekspert ds. legislacji BAS - rafal.dubowski@sejm.gov.pl • https://orcid.org/0000-0001-7852-4275

\section{Przedmiot oceny}

Przedmiotem oceny są skutki, które będzie rodzić lub może powodować wprowadzenie regulacji zawartej w rządowym projekcie ustawy o Rzeczniku Praw Podatnika (druk sejmowy nr 3516; dalej: projekt). W ocenie uwzględniono stan prawny na dzień 5 czerwca $2019 \mathrm{r}$.

1 Ocena skutków prawnych regulacji zawartej w rządowym projekcie ustawy o Rzeczniku Praw Podatnika (druk nr 3516) sporządzona 28 czerwca 2019 r. na zlecenie zastępcy Szefa Kancelarii Sejmu; BAS-WAP 1102/19. 


\section{Zakres proponowanych zmian}

Jak deklaruje projektodawca, proponowane rozwiązania mają na celu zagwarantować prawa podatnikom i zwiększyć ich poczucie bezpieczeństwa w kontaktach z organami administracji skarbowej. Realizacji tego celu ma służyć utworzenie instytucji Rzecznika Praw Podatnika², który będzie stał na straży praw podatnika, w szczególności poszanowania zasady pogłębiania zaufania do organów podatkowych, bezstronności, równego i sprawiedliwego traktowania podatnika, respektowania jego słusznych interesów oraz racjonalności działania organów podatkowych wobec podatnika (art. 1 projektu).

Zgodnie z projektowanymi rozwiązaniami Rzecznik byłby powoływany przez Prezesa Rady Ministrów na wniosek ministra właściwego do spraw finansów publicznych (art. 4 ust. 1 projektu), przy czym kandydat na Rzecznika byłby przedstawiany przez ministra po przeprowadzeniu otwartego i konkurencyjnego naboru (art. 4 ust. 2 projektu). Kadencja Rzecznika trwałaby 6 lat (art. 4 ust. 3 projektu), a ponowny wybór tej samej osoby na to stanowisko byłby niedopuszczalny (art. 4 ust. 4 projektu).

Artykuł 11 ust. 1 projektu przesądza, że Rzecznik nie mógłby wykonywać innej pracy ani innych zajęć zawodowych, w tym działalności gospodarczej, z wyjątkiem zajmowania stanowiska dydaktycznego, badawczego lub badawczo-dydaktycznego w podmiotach, o których mowa w art. 7 ust. 1 ustawy z 20 lipca 2018 r. - Prawo o szkolnictwie wyższym i nauce (Dz.U. poz. 1668, ze zm.). Ponadto według ust. 2 tego artykułu Rzecznik nie mógłby:

- należeć do partii politycznej,

- należeć do związku zawodowego,

- prowadzić działalności publicznej niedającej się pogodzić z godnością urzędu.

Zgodnie z art. 12 ust. 1 projektu Rzecznik wykonywałby swoje zadania przy pomocy:

- nie więcej niż 16 zastępców Rzecznika,

- nie więcej niż 32 przedstawicieli terenowych Rzecznika,

- Biura Rzecznika Praw Podatnika.

W zakresie ochrony praw podatnika Rzecznik mógłby między innymi:

2 Ponieważ projektowana ustawa ma zostać wprowadzona odrębną ustawą, przepis o utworzeniu instytucji Rzecznika Praw Podatnika został - zgodnie z $\$ 48$ w związku z $\$ 35$ rozporządzenia Prezesa Rady Ministrów w sprawie „Zasad techniki prawodawczej” (t.j. Dz.U. 2016, poz. 283), dalej: ZTP - zawarty w projekcie obejmującym przepisy wprowadzające (zob. art. 198 ust. 1 rządowego projektu ustawy - Przepisy wprowadzające ustawę - Ordynacja podatkowa i ustawę o Rzeczniku Praw Podatnika, druk nr 3518). 
- występować do właściwego organu z wnioskiem o podjęcie inicjatywy ustawodawczej albo wydanie innego aktu normatywnego w sprawach podatkowych,

- uczestniczyć jako mediator w postępowaniu podatkowym i postępowaniu sądowoadministracyjnym,

- występować do właściwego organu z wnioskiem o wydanie interpretacji indywidualnej w sprawie podatnika, który nie ma możliwości samodzielnego złożenia wniosku o wydanie interpretacji indywidualnej lub gdy sprawia mu to nadmierną trudność,

- występować do ministra właściwego do spraw finansów publicznych z wnioskiem o wydanie interpretacji ogólnej:

a) w sprawach budzących wątpliwości interpretacyjne oraz mających istotne znaczenie dla grupy podatników,

b) jeżeli może to spowodować znaczne obniżenie liczby wniosków o wydanie interpretacji indywidualnych - przedstawiając własne stanowisko w sprawie oceny prawnej zagadnienia będącego przedmiotem wniosku,

- występować do ministra właściwego do spraw finansów publicznych z wnioskiem o wydanie objaśnień podatkowych w sprawach będących źródłem poważnych wątpliwości interpretacyjnych,

- występować z wnioskiem do Naczelnego Sądu Administracyjnego o podjęcie uchwały mającej na celu wyjaśnienie przepisów prawnych, których stosowanie wywołało rozbieżności w orzecznictwie sądów administracyjnych,

- zwracać się o wszczęcie postępowania podatkowego oraz wnieść skargę do sądu administracyjnego, skargę kasacyjną do Naczelnego Sądu Administracyjnego, zażalenie w postępowaniu sądowoadministracyjnym, skargę o wznowienie postępowania, które zostało zakończone prawomocnym orzeczeniem sądu administracyjnego i skargę o stwierdzenie niezgodności z prawem prawomocnego orzeczenia sądu administracyjnego, a także uczestniczyć w postępowaniu podatkowym i postępowaniu sądowoadministracyjnym (art. 15 ust. 1 projektu).

Wydatki związane z funkcjonowaniem Rzecznika byłyby ujmowane w ustawie budżetowej i pokrywane z budżetu państwa, z części, której dysponentem jest minister właściwy do spraw finansów publicznych (art. 26 ust. 2 projektu).

\section{Podmioty, na które będzie oddziaływać regulacja zawarta w projekcie}

Projektowana regulacja będzie oddziaływać na:

- podatników, płatników, inkasentów, następców prawnych oraz osoby trzecie w rozumieniu przepisów Ordynacji podatkowej (t.j. Dz.U. 2019, poz. 900), (art. 2 projektu) oraz organizacje przedsiębiorców i samorządy zawodowe 
przez przyznanie uprawnienia do złożenia wniosku o podjęcie czynności przez Rzecznika (art. 17 ust. 2 projektu),

- Marszałka Sejmu przez to, że Rzecznik, na wniosek Marszałka Sejmu, będzie obowiązany przedstawić informacje wynikające z jego działalności (art. 25 ust. 2 projektu),

- Sejm, Senat - Rzecznik będzie mógł przedkładać Sejmowi i Senatowi informacje wynikające $\mathrm{z}$ jego działalności, a także opinie o projektach aktów normatywnych mogących wpływać na prawa podatnika (art. 25 ust. 1 projektu),

- Rzecznika Małych i Średnich Przedsiębiorców - przez nałożenie na Rzecznika Praw Podatnika obowiązku poinformowania Rzecznika Małych i Średnich Przedsiębiorców o zamiarze wykonania uprawnień, o których mowa w art. 15 ust. 1 pkt 2-13 projektu, w sprawach dotyczących mikroprzedsiębiorców oraz małych i średnich przedsiębiorców ${ }^{3}$,

- Rzecznika Praw Obywatelskich - Rzecznik Praw Podatnika mógłby występować do Rzecznika Praw Obywatelskich z wnioskiem o skierowanie przez niego wniosku do Trybunału Konstytucyjnego w sprawie, o której mowa w art. 188 Konstytucji, dotyczącej praw podatnika (art. 15 ust. 1 pkt 14 projektu),

- sądy administracyjne - Rzecznik będzie mógł m.in.: wystąpić z wnioskiem do NSA o podjęcie uchwały mającej na celu wyjaśnienie przepisów prawnych; wnieść skargę do sądu administracyjnego i skargę kasacyjną do Naczelnego Sądu Administracyjnego oraz wnieść skargę o stwierdzenie niezgodności z prawem prawomocnego orzeczenia (art. 15 ust. 1 pkt 7 projektu),

- organy Krajowej Administracji Skarbowej, ministra właściwego do spraw finansów publicznych - Rzecznik będzie miał możliwość wystąpienia do właściwego organu podatkowego $\mathrm{z}$ wnioskiem o: wydanie interpretacji indywidulanej (art. 15 ust. 1 pkt 3 projektu), wydanie interpretacji ogólnej (art. 15 ust. 1 pkt 4 projektu), wydanie ogólnych wyjaśnień przepisów prawa podatkowego dotyczących stosowania tych przepisów (objaśnień podatkowych), (art. 15 ust. 1 pkt 5 projektu), wszczęcie postępowania (art. 15 ust. 1 pkt 7 projektu), uchylenie lub zmianę decyzji ostatecznej (art. 15 ust. 1 pkt 12 projektu),

- Prezesa Rady Ministrów - powoływanie Rzecznika (art. 4 ust. 1 projektu), otrzymywanie informacji o działalności Rzecznika oraz o stanie przestrzegania praw podatnika (art. 24 ust. 1 projektu),

- organy nadzoru, prokuratury i kontroli państwowej, zawodowej lub społecznej, do których Rzecznik będzie mógł zwrócić się o zbadanie sprawy lub jej części (art. 20 projektu).

3 Zob. art. 16 projektu oraz art. 1 ust. 2 ustawy z 6 marca 2018 r. o Rzeczniku Małych i Średnich Przedsiębiorców, Dz.U. poz. 648; dalej: ustawa o RMiŚP. 


\section{Uwagi szczegółowe}

\section{Instytucje chroniące prawa podatnika}

Podstawowym skutkiem prawnym przyjęcia projektu będzie określenie zadań, kompetencji i zakresu działania Rzecznika Praw Podatnika - organu, który ma zostać utworzony na podstawie art. 198 ust. 1 rządowego projektu ustawy - Przepisy wprowadzające ustawę - Ordynacja podatkowa i ustawę o Rzeczniku Praw Podatnika (druk nr 3518). Oceniając ten skutek, trzeba zauważyć, że na gruncie obowiązujących regulacji istnieją już organy chroniące prawa różnych podmiotów, w tym prawa podatnika. Najszersze kompetencje w tym zakresie ma Rzecznik Praw Obywatelskich, będący organem konstytucyjnym państwa. Poza tym odpowiednie działania na rzecz podatników może podejmować także Rzecznik Małych i Średnich Przedsiębiorców ${ }^{4}$. O tym, że działania, które będzie mógł realizować Rzecznik Praw Podatnika, pokrywają się z tymi, które podejmuje Rzecznik Małych i Średnich Przedsiębiorców na podstawie obowiązujących przepisów, świadczy w szczególności to, iż w sprawach podatkowych dotyczących mikroprzedsiębiorców oraz małych i średnich przedsiębiorców 12 z 14 kompetencji (określonych w art. 15 ust. 1 projektu) Rzecznik Praw Podatnika będzie mógł realizować dopiero po poinformowaniu Rzecznika Małych i Średnich Przedsiębiorców i wówczas, gdy ten nie zdecyduje się na podjęcie czynności we własnym zakresie (art. 16 projektu).

Ten przepis może stawiać pod znakiem zapytania potrzebę utworzenia nowej instytucji Rzecznika Praw Podatnika. Alternatywnym rozwiązaniem mogłoby być zreformowanie istniejących organów i ukierunkowanie ich działalności na ochronę praw podatnika. Niemniej trzeba zaznaczyć, że utworzenie instytucji Rzecznika Praw Podatnika nie jest pozbawione korzyści. W szczególności rozwiązanie to zapewni, że środki przeznaczone na ochronę podatników będą wykorzystywane na ten konkretny cel, a ponadto będzie ono dawało podatnikowi kolejny instrument, z którego będzie mógł on skorzystać wówczas, gdy uzna, że jego prawa są zagrożone.

4 Jak stanowi art. 1 ust. 2 ustawy z 15 lipca 1987 r. o Rzeczniku Praw Obywatelskich (t.j. Dz.U. 2018, poz. 2179, ze zm.; dalej: ustawa o RPO), Rzecznik stoi na straży wolności i praw człowieka i obywatela określonych w Konstytucji Rzeczypospolitej Polskiej oraz $w$ innych aktach normatywnych, $w$ tym również na straży realizacji zasady równego traktowania. Natomiast art. 1 ust. 1 ustawy o RMiŚP przewiduje, że: Rzecznik Małych i Średnich Przedsiębiorców stoi na straży praw mikroprzedsiębiorców oraz małych $i$ średnich przedsiębiorców, w szczególności poszanowania zasady wolności działalności gospodarczej, pogłębiania zaufania przedsiębiorców do władzy publicznej, bezstronności i równego traktowania, zrównoważonego rozwoju oraz zasady uczciwej konkurencji i poszanowania dobrych obyczajów oraz stusznych interesów przedsiębiorców. Realizując te zadania, każdy z tych rzeczników może w szczególności zwrócić się o wszczęcie postępowania administracyjnego, wnieść skargę do sądu administracyjnego, a także uczestniczyć w tych postępowaniach - na prawach przysługujących prokuratorowi (art. 14 pkt 6 ustawy o RPO oraz art. 9 ust. 1 pkt 8 ustawy o RMiŚP). 


\section{Pozycja ustrojowa Rzecznika Praw Podatników}

Jak wskazano wyżej, Rzecznik Praw Podatnika ma stać na straży praw podatnika $\mathrm{w}$ jego stosunkach z organami podatkowymi. Wydaje się jednak, że jego pozycja ustrojowa może utrudniać realizację tego zadania. Warto zauważyć bowiem, że zgodnie z projektem Rzecznik byłby powoływany przez Prezesa Rady Ministrów, na wniosek ministra właściwego do spraw finansów publicznych, a więc przez ministra, który według art. $13 \mathrm{~b} \$ 2 \mathrm{~b}$ Ordynacji podatkowej jest jednym z organów podatkowych ${ }^{5}$. Ponadto na gruncie projektowanych rozwiązań zależność Rzecznika od ministra właściwego do spraw finansów przejawia się także w aspekcie organizacyjnym oraz finansowym. Jak przewiduje art. 12 ust. 11 projektu, minister właściwy do spraw finansów publicznych nadawałby statut Biuru Rzecznika, a poza tym zgodnie z ust. 11 tego artykułu mógłby on, w drodze zarządzenia, wskazać jednostki mu podległe lub przez niego nadzorowane, w których udostępnione zostałyby pomieszczenia wraz z odpowiednią infrastrukturą do wykonywania zadań przez pracowników Biura. Co więcej, według art. 26 ust. 2 projektu wydatki związane $z$ funkcjonowaniem Rzecznika byłyby ujmowane w ustawie budżetowej i pokrywane z budżetu państwa, z części, której dysponentem jest minister właściwy do spraw finansów publicznych.

Jak przekonuje projektodawca, Rzecznik Praw Podatnika będzie cieszył się szeroką niezależnością od ministra właściwego do spraw finansów publicznych z uwagi na to, że projekt zakłada wprowadzenie zasady kadencyjności (określona osoba będzie mogła piastować ten urząd przez jedną 6-letnią kadencję) oraz zawiera katalog przesłanek odwołania Rzecznika (uzasadnienie, s. 7). Jednak argumentacja taka jest przekonująca tylko częściowo, ponieważ na niezależność instytucji wpływają nie tylko gwarancje nieusuwalności kierującej nią osoby, ale także rozwiązania zapewniające niezależność organizacyjną i finansową całej instytucji. Natomiast zgodnie z art. 26 ust. 1 projektu Biuro Rzecznika będzie stanowiło państwową jednostkę budżetową w rozumieniu ustawy z 27 sierpnia 2009 r. o finansach publicznych (t.j. Dz.U. 2019, poz. 869). Wobec tego, biorąc również pod uwagę, że dysponenci części budżetowych mają wpływ na kształt planów finansowych jednostek budżetowych ${ }^{6}$, trzeba zauważyć, iż minister właś-

5 Na przykład Rzecznik Praw Pacjenta powoływany jest przez Prezesa Rady Ministrów, bez udziału ministra właściwego do spraw zdrowia (art. 44 ust. 1 ustawy z 6 listopada 2008 r. o prawach pacjenta i Rzeczniku Praw Pacjenta, t.j. Dz.U. 2019, poz. 1127; dalej: ustawa o prawach pacjenta). Z kolei Rzecznika Praw Obywatelskich powołuje Sejm za zgodą Senatu na wniosek Marszałka Sejmu albo grupy 35 posłów (art. 3 ust. 1 ustawy o RPO).

6 Zob. E. Malinowska-Misiąg, Art. 11 ustawy o finansach publicznych [w:] Ustawa o finansach publicznych. Ustawa o odpowiedzialności za naruszenie dyscypliny finansów publicznych. Komentarz, red. W. Misiąg, Warszawa 2019, nb 8, gdzie autorka wyjaśnia: [w] przypadku państwowych jednostek budżetowych rozporządzenie Min. Finansów $z$ 7.12.2010 r. odsyła m.in. do art. 143, określającego termin przekazywania informacji 
ciwy do spraw finansów publicznych będzie mógł pośrednio oddziaływać na działalność Rzecznika Praw Podatnika, a w szczególności będzie mógł niebezpośrednio wpływać na jej zakres.

W związku z powyższym należy stwierdzić, że z uwagi na to, iż według projektowanych rozwiązań Rzecznik Praw Podatnika będzie organem częściowo zależnym od jednego $\mathrm{z}$ organów podatkowych, osiągnięcie celów zakładanych przez projektodawcę może być utrudnione. Przy czym trzeba wyjaśnić, że Rzecznik Praw Podatnika nie jest organem konstytucyjnym i dlatego wprowadzenie regulacji przewidujących ograniczenie niezależności Rzecznika jest konstytucyjnie dopuszczalne, choć - co należy dodać - z punktu widzenia celu projektu, którym jest ochrona praw podatnika, może budzić wątpliwości.

\section{Zastępcy Rzecznika i jego przedstawiciele terenowi}

Jak przewiduje art. 12 ust. 1 projektu, Rzecznik wykonywałby swoje zadania przy pomocy:

- nie więcej niż 16 zastępców Rzecznika,

- nie więcej niż 32 przedstawicieli terenowych Rzecznika,

- Biura Rzecznika Praw Podatnika.

A zatem, szeroko rozumiana kadra kierownicza nowej instytucji może liczyć 49 osób. Chociaż z brzmienia art. 12 ust. 1 w związku z art. 12 ust. 2 i 3 projektu wynika, że Rzecznik może powołać mniej niż 16 zastępców i 32 przedstawicieli terenowych, to - jak wskazano w rządowej „Ocenie skutków regulacji” (dalej: OSR) - planowane jest utworzenie 16 etatów dla zastępców oraz 32 dla przedstawicieli terenowych (OSR, s. 7). Ponadto w dokumencie tym wyjaśniono, że

przez dysponentów części budżetowych $w$ celu opracowania projektów planów finansowych jednostek budżetowych oraz termin przekazania przez jednostki budżetowe opracowanych projektów właściwym dysponentom części budżetowej. Dysponenci weryfikuja projekt planu finansowego jednostki $w$ zakresie zgodności $z$ projektem ustawy budżetowej, a w razie stwierdzenia niezgodności wprowadzają $w$ nim zmiany. Od początku roku budżetowego do dnia opracowania planu finansowego na podstawie informacji o kwotach dochodów i wydatków wynikających $z$ ustawy budżetowej projekt planu finansowego stanowi podstawe gospodarki finansowej państwowej jednostki budżetowej. Po ogtoszeniu ustawy budżetowej dysponenci części budżetowej przekazuja kierownikom podległych państwowych jednostek budżetowych, w terminie określonym $w$ art. 146 ust. 1 komentowanej ustawy, informacje o kwotach dochodów $i$ wydatków budżetowych, niezbędne do sporządzenia planów finansowych tych jednostek. Plany, których podstawe stanowia przygotowane wcześniej projekty, opracowywane sa w ustalonej w rozporządzeniu szczegółowości - kierownicy państwowych jednostek budżetowych maja na to dwa tygodnie. Opisany powyżej tryb przygotowywania planów finansowych świadczy o stosunkowo niedużej samodzielności kierownika jednostki budżetowej w zakresie ustalania planu swojej jednostki. 
w Biurze Rzecznika zostaną zatrudnieni także inni pracownicy, w tym pracownicy do zapewnienia obsługi administracyjno-biurowej (87 etatów) (ibidem). W OSR wskazano również, iż razem planuje się utworzyć 136 etatów (ibidem). Powyższe oznacza, że 36\% planowanych etatów w Biurze Rzecznika to etaty kierownicze.

Nie negując, że sprawy podatkowe odznaczają się wysokim stopniem skomplikowania, wydaje się, iż możliwość powołania 16 zastępców Rzecznika oraz 32 przedstawicieli terenowych może nie być właściwym rozwiązaniem prawno-organizacyjnym. Warto dostrzec bowiem, że Rzecznik Praw Obywatelskich (wykonujący zadania o znacznie szerszym zakresie merytorycznym, wykraczającym poza sprawy podatkowe), może powołać nie więcej niż trzech zastępców (art. 20 ust. 3 ustawy o RPO), Rzecznik Praw Pacjenta - nie więcej niż dwóch (art. 46 ust. 1 ustawy o prawach pacjenta), a Rzecznik Praw Dziecka oraz Rzecznik Małych i Średnich Przedsiębiorców - tylko jednego ${ }^{7}$. Ponadto trzeba zauważyć, iż zgodnie z art. 22 ustawy o RPO Rzecznik Praw Obywatelskich może, za zgodą Sejmu, ustanowić swoich pełnomocników terenowych i na tej podstawie obecnie działa tylko trzech tego rodzaju pełnomocników (RPO ma pełnomocników terenowych w Gdańsku, Katowicach i Wrocławiu). Z kolei Rzecznik Praw Pacjenta oraz Rzecznik Praw Dziecka w ogóle nie mogą ustanawiać pełnomocników terenowych.

Mając na uwadze, że w instytucjach pełniących zadania podobne do tych, które pełnić będzie Rzecznik Praw Podatnika, kadra zastępców oraz przedstawicieli terenowych nie jest tak rozbudowana, w toku prac nad projektem należałoby wyjaśnić, jakie argumenty przemawiają za takim rozwiązaniem oraz w jaki sposób wpłynie ono na koszty funkcjonowania Biura Rzecznika Praw Podatnika.

\section{Wymagania dla kandydata na Rzecznika}

W art. 3 projektu zostały określone wymagania, które powinien spełniać Rzecznik Praw Podatnika. Według pkt 6 tego artykułu Rzecznikiem może być osoba, która ma doświadczenie w zakresie stosowania prawa podatkowego oraz przez co najmniej 5 lat:

- wykonywała zawód doradcy podatkowego lub

- zajmowała stanowisko sędziego sądu administracyjnego, lub

- wykonywała zawód adwokata lub radcy prawnego, lub

- pełniła funkcję organu podatkowego, lub

- pozostawała na stanowisku związanym ze stosowaniem prawa podatkowego w urzędach obsługujących organy podatkowe.

Można przypuszczać, że skutkiem przyjęcia tego przepisu będą wątpliwości interpretacyjne. Nie jest bowiem jasne, co oznacza „doświadczenie w zakresie

Zob. art. 13 ust. 3 ustawy z 6 stycznia 2000 r. o Rzeczniku Praw Dziecka, t.j. Dz.U. 2017, poz. 922, ze zm., oraz art. 7 ustawy o RMiŚP. 
stosowania prawa podatkowego". Użycie spójnika „oraz” wskazuje na to, że doświadczenie w zakresie stosowania prawa podatkowego nie jest tożsame $\mathrm{z}$ wykonywaniem zawodu doradcy podatkowego ani $\mathrm{z}$ wykonywaniem innego zawodu czy też zajmowaniem określonego stanowiska wskazanego w art. 3 pkt 6 przez co najmniej 5 lat. Być może w praktyce przyjmowano by, że wykonywanie zawodu doradcy podatkowego, pełnienie funkcji organu podatkowego oraz zajmowanie stanowiska związanego ze stosowaniem prawa podatkowego implikuje posiadanie doświadczenia zawodowego, o którym mowa $\mathrm{w}$ tym przepisie, niemniej nadal trudno byłoby ustalić, jak duże (ilu letnie) doświadczenie zawodowe $\mathrm{w}$ zakresie stosowania prawa podatkowego powinni mieć sędziowie sądów administracyjnych, adwokaci lub radcowie prawni, a więc przedstawiciele tych zawodów, które ze swej istoty nie muszą być związane ze stosowaniem prawa podatkowego. Wątpliwości może budzić też samo pojęcie „stosowania prawa”, albowiem w wąskim ujęciu prawo stosują wyłącznie organy władzy publicznej, a więc nie stosują prawa ani adwokaci, ani radcowie prawni, którzy świadczą pomoc prawną. Nawet jeśli założyć, że świadczenie pomocy prawnej jest stosowaniem prawa, to praktyczne problemy związane $\mathrm{z}$ art. 3 pkt 6 projektu nadal pozostaną, ponieważ o ile w przypadku sędziego posiadanie doświadczenia w stosowaniu prawa podatkowego można stwierdzić na podstawie kategorii spraw rozpatrywanych przez wydział sądu, w którym orzekał, o tyle w przypadku adwokata lub radcy prawnego posłużenie się obiektywnymi kryteriami mogłoby być czasem utrudnione (wszak nierzadko prawnicy zajmują się różnymi kategoriami spraw).

Wątpliwości interpretacyjne może budzić także niejednoznaczne pojęcie „stanowiska związanego ze stosowaniem prawa podatkowego w urzędach obsługujących organy podatkowe", wykorzystane w art. 3 pkt 6 lit. e. Przepis ten może też prowadzić do nadużyć, ponieważ $w$ istocie $w$ urzędach obsługujących organy podatkowe każde stanowisko jest (co najmniej pośrednio) związane ze stosowaniem prawa podatkowego.

\section{Podsumowanie}

- Na gruncie obowiązujących regulacji istnieją już organy chroniące prawa różnych podmiotów, w tym prawa podatnika. Kompetencje w tym zakresie ma Rzecznik Praw Obywatelskich oraz Rzecznik Małych i Średnich Przedsiębiorców. Alternatywnym rozwiązaniem wobec utworzenia instytucji Rzecznika Praw Podatnika mogłoby być zreformowanie istniejących organów i ukierunkowanie ich działalności na ochronę praw podatnika. Niemniej utworzenie instytucji Rzecznika Praw Podatnika przyniesie pewne korzyści. W szczególności rozwiązanie to zapewni, że środki przeznaczone na ochronę podatników będą wykorzystywane na ten konkretny cel, a ponadto będzie ono dawało podatnikowi kolejny instrument, z którego będzie mógł on skorzystać wówczas, gdy uzna, iż jego prawa są zagrożone. 
- Zgodnie z art. 4 ust. 1 projektu Rzecznik Praw Podatnika byłby powoływany przez Prezesa Rady Ministrów, na wniosek ministra właściwego do spraw finansów publicznych, a więc przez ministra, który według art. 13b $\$ 2 \mathrm{~b}$ Ordynacji podatkowej jest jednym z organów podatkowych. Ponadto na gruncie projektowanych rozwiązań zależność Rzecznika od ministra właściwego do spraw finansów przejawia się także w aspekcie organizacyjnym (nadawanie statutu Biura, udostępnianie pomieszczeń $z$ odpowiednią infrastrukturą) oraz finansowym (pokrywanie wydatków z budżetu państwa, z części, której dysponentem jest minister właściwy do spraw finansów publicznych). W związku z tym Rzecznik Praw Podatnika będzie organem częściowo zależnym od jednego z organów podatkowych (tj. od ministra właściwego do spraw finansów publicznych) i dlatego osiągnięcie celów zakładanych przez projektodawcę może być utrudnione. Przy czym Rzecznik Praw Podatnika nie jest organem konstytucyjnym i dlatego wprowadzenie regulacji przewidujących ograniczenie niezależności Rzecznika jest konstytucyjnie dopuszczalne, choć - jak wskazano - może budzić wątpliwości z punktu widzenia celu projektu, którym jest ochrona praw podatnika.

- Według art. 12 ust. 1 pkt 1 i 2 Rzecznik wykonywałby swoje zadania przy pomocy nie więcej niż 16 zastępców Rzecznika oraz nie więcej niż 32 przedstawicieli terenowych. Choć projekt dopuszcza, aby Rzecznik powołał mniej niż 16 zastępców i 32 przedstawicieli terenowych, to - jak wynika z OSR - planowane jest utworzenie 16 etatów dla zastępców i 32 dla przedstawicieli terenowych. Ponadto w dokumencie tym wskazuje się, że w Biurze Rzecznika zostaną zatrudnieni także inni pracownicy, w tym pracownicy do zapewnienia obsługi administracyjno-biurowej (87 etatów). A więc, razem planuje się utworzyć 136 etatów. Powyższe oznacza, że 36\% planowanych etatów w Biurze Rzecznika (49 z 136 etatów) to etaty kierownicze. Ponieważ Rzecznik Praw Obywatelskich (wykonujący zadania o znacznie szerszym zakresie merytorycznym, wykraczającym poza sprawy podatkowe), może powołać nie więcej niż trzech zastępców, Rzecznik Praw Pacjenta - nie więcej niż dwóch, a Rzecznik Praw Dziecka oraz Rzecznik Małych i Średnich Przedsiębiorców - tylko jednego, w toku prac nad projektem należałoby wyjaśnić, jakie argumenty przemawiają za proponowanym rozwiązaniem oraz w jaki sposób wpłynie ono na koszty funkcjonowania Biura Rzecznika Praw Podatnika.

- Wątpliwości interpretacyjne może budzić art. 3 pkt 6 projektu, który formułuje wymogi dotyczące doświadczenia zawodowego dla kandydata na Rzecznika Praw Podatnika.

\section{Bibliografia}

Malinowska-Misiąg E., Art. 11 ustawy o finansach publicznych [w:] Ustawa o finansach publicznych. Ustawa o odpowiedzialności za naruszenie dyscypliny finansów publicznych. Komentarz, red. W. Misiąg, Warszawa 2019. 